\title{
Greenland Culture. (2) The Eskimo*
}

$\mathrm{T}$ HREE reports issued recently by the Commission for Scientific Research in Greenland deal with the culture of the Eskimo in East Greenland.

(1) Kangerdlugssuak District. An expedition of the Scoresby Sound. Committee, of which Einar Mikkelsen was in charge and Magnus Degerbøl responsible for the archæological investigation, examined the coast from Cape Dalton to Kangerdlugssuak, an area of great interest, as it is situated between the Angmagssalik Settlement in the south and the former Eskimo area of settlement in north-eastern Greenland from Scoresby Sound northwards. Before 1932, this region had been traversed only by the Amdrup expedition of 1900 , which found a number of deserted Eskimo habitations, graves, tent-rings, etc., at the mouth ${ }^{-}$of Kangerdlugssuak, but no remains from Kangerdlugssuak to Scoresby Sound, nor north of Cape Dalton to Dunholm, where, however, Eskimo remains existed. The present expedition confirmed this result, and it was only at Miki's Fjord, a few kilometres east of Kangerdlugssuak, that it was possible to prove former habitation. An inference that Irminger's Fjord was once the site of a habitation has later (1935) been proved to be correct.

Miki's Fjord is well suited to habitation. Here a ridge runs north-south, with terraces sloping to the south. A firm rocky ledge affords room for movement and building, with easy access to the sea. The only drawback is an absence of fresh water. On this terrace were five sets of house ruins, at different levels, the lowest being the largest and best preserved, though there is reason to believe that the smaller were parts only of houses originally larger. All the houses, with one exception of indeterminate shape, were rectangular. The objects found in the houses were essentially of the same culture period, and belong to the Inugsuk culture. The number of skeletal remains found in the house, together with the secondarily formed small houses, suggests that the population did not emigrate, but perished in their homes, possibly from malnutrition due to a lack of vegetable food. Animal food was evidently plentiful.

* The Scoresby Sound Committee's 2nd East Greenland Expedition in 1932 to King Christian IX's Land-The Former Eskimo Habitation in the Kangerdlugssuak District, East Greenland. By Magnus Degerbøl (Meddelelser om Grønland, Bind 104, Nr. 10.) Pp. $48+1$ plate. $2.50 \mathrm{kr}$. 6 og 7 Thule-Expedition til Sydøstgronland 1931-33-The Former Eskimo Settlements on Frederik VI's Coast. By Therkel Mathiassen. (Meddelelser om Gronland, Bind 109, Nr. 2.) Pp. 58. $2.50 \mathrm{kr}$.

The Eskimo Archaeology of Julianehaab District, with a Brief Summary of the Prehistory of the Greenlanders. By Therkel Mathiassen in collaboration with Erik Holtved. (Meddelelser om Grenland, Bind 118, Nr. 1.) Pp. $141+4$ plates. $7.00 \mathrm{kr}$

(København: C. A. Reitzels Forlag, 1936.)

The first article appeared in NATURE of July 10, p. 52.
A woman's grave found on a small headland is one of the largest grave finds in Greenland, and contains several objects not known from other finds. An entirely new element, not previously known in Eskimo culture, is eighty-four beads, small white circular disks of mussel shell, while a needle case containing two needles of walrus ivory is the first example of a bone sewing needle from Greenland. An explanation put forward by Th. Mathiassen of the distinctive character of certain of the cultural objects is that the length of occupation gave rise to independent development.

The character of the remains and deposits shows that the occupation was one of considerable length. Immigration probably took place at the end of the fifteenth, or beginning of the sixteenth, century; and occupation, it is thought, may have lasted until so late as the eighteenth century.

(2) Frederik VI's Coast. An expedition in 193133, of which Knud Rasmussen was leader, made a study of former Eskimo settlements on this coast between Prince Christian Sound on the south and Ikerssuaq, the boundary of the Angmagssalik district, on the north, with the purpose of determining the number and character of the Eskimo settlements which were known to exist, but of which exact information was lacking. As many settlements as possible were inspected, and a few excavations were made. From all sources, including those already in print, as well as from information received, three hundred and eighty-two settlements were recorded in eleven regions. In 1931 Erik Holtved excavated eleven house sites, producing seventy-two artefacts, and in $1932 \mathrm{Th}$. Mathiassen excavated twenty-one ruins, producing 526 specimens.

The house types fall into the following categories: (1) small, rounded, and much overgrown and flattened-out houses; (2) small, four-sided, partly flattened-out houses; (3) large, four-sided, partly overgrown houses; (4) houses known to have been inhabited in the nineteenth and twentieth centuries.

The most important site investigated was Ruinnæsset on Skjoldunge Fjord. Here Knud Rasmussen discovered a great house complex. From this site alone 329 specimens were obtained.

In regard to the character and succession of cultures, it would appear that the earliest house ruins on this coast are probably contemporaneous with the earliest houses in Angmagssalik, and belong to the end of the fourteenth, or beginning of the fifteenth, centuries. They are small, round, 
and dug down into the ground, with poorly built walls, paved floors, sunk passages and often a cooking extension. Sometimes two or three are built together, forming a clover-leaf shaped complex. Their culture shows evidence of some whaling. There are no glass beads The culture is of the same type as the Angnagssalik, and belongs to the Inugsuk culture.

The seventeenth-eighteenth century house, of which sixty small, and seventy-seven large, were seen, is distinctly four-sided. At first small ; later, in the eighteenth century, it becomes the large common house, which seems to have been introduced by a migration from the west coast, reaching as far as Angmagssalik. Houses of this type were seen at fifty-one settlements. The culture is particularly well displayed in the finds from Ruinnæsset. It is derived from the contemporary South-west Greenland culture, but with a special south-east coast stamp. This find is given a special character by the many drilled seal jaws.

Fifty-six houses on this coast are known to have been inhabited in the nineteenth century, or later. Records of this period were made on the voyage by W. A. Graah in 1829-30, when 536 Greenlanders lived here in summer. The movement to the west coast had already begun, the last southeasters moving to the southern part of the west coast in 1900. At the present time, it is visited occasionally only for sealing.

(3) Julianehaab District. In the course of an expedition sent out by the Commission in 1934 a comprehensive survey was made of the Julianehaab district, the most southerly part of Greenland's west coast, and its most fertile and thickly populated area. It forms a connecting link between East and West Greenland, and was the site of the principal Norse settlement. The main interest of the expedition was the investigation of early Eskimo settlement, of which very little systematic knowledge was previously available.

It is now known that there are two hundred and forty-six places in the district where there have been Eskimo winter settlements. Of these, one hundred and thirty were visited. Excavation was possible on four sites only. Here fifty-six house ruins, four hundred square metres of midden, and twenty-three graves were examined, producing 1,808 specimens and fifty-seven skeletons. The house types are an early group of round or rounded small houses, sometimes two or three built together with a common passage ; two types of the seventeenth-eighteenth century, distinctive, rectangular with a high stone wall and a sunken passage at right angles to the house, large ; but the later type small; and fourthly, the nineteenth century house, small, rectangular, with high stone and turf walls and a passage in prolongation of the longitudinal axis, often with a bend and not sunken, and with a kitchen or storehouse as an offset in the angle. This last is the type now in use, though it is being displaced by wooden houses.

The conditions for the preservation of cultural objects in the Julianehaab district are adverse in the extreme, owing to the succession of frost and thaw and the percolation of water. As a result of this, most of the ruins contained no bones or wood.

In the houses of the earliest type, most of the objects are of the kind known from other sites in Greenland and belonging to the Inugsuk culture. Among the most interesting and important were the lamps, which by their varying form afford a guide to chronology. Those with wick-ledge or knobs are a characteristic type of the culture. A number of objects of Norse origin probably represent spoil from the houses of the Norse settlement, which were deserted when the settlement decayed soon after the first appearance of the Eskimo in 1379. The earliest Eskimo culture of the District may be dated as lying within the period 13501650. Early settlement was invariably, so far as observed, half-way up the fjords, the situation most favourable for ice hunting. The principal quarry, as shown by the bones from the sites, was the seal, but the caribou and the whale were of importance.

The finds of cultural objects from the seventeenth-eighteenth century houses do not differ essentially from finds from other parts of Greenland. Glass beads were found in most of the ruins, but in no great numbers. The principal varieties are the large opalescent, the large facetted-blue, yellow and colourless-a large black, a large rather flat dark blue, and a cylindrical bead, red with white longitudinal stripes. Although the culture as a whole compares with that of West Greenland, it has in its harpoon-heads, arrowheads and lamps an older stamp, as indicative of an out-of-the-way situation. The same oldfashioned typeš are recognizable at Angmagssalik, the similarity appearing in a relatively large number of objects, such as salmon spear, fish hooks, pendants, etc. The animal bones show that sealing had been the principal occupation; but the inhabitants also hunted whales, caribou, white-whales, bears, foxes and fowl. In certain periods there have been many fish, especially cod. There is also a surprisingly large number of dog bones, but no proof of sledge traction.

The development of the kayak, and the consequent increased utilization of sea locomotion for hunting and fishing, led to a diffusion of settlement, the number of small settlements increasing markedly. In the following period of the nineteenth and twentieth centuries, however, the number of 
small settlements declined, and large settlements again prevailed, in order that the population might be near the centres of commerce and industry, which grew up with European settlement. The introduction of wooden houses put a further check on the nomadic habits of the people.

The mummy caves at Querrortut were also investigated. Though much disordered by a previous party of archæological investigation, remains of desiccated bodies were found, which may be attributed to interment and not to incarceration and death from starvation. The occurrence of grave goods points to the pagan period, and tentatively a sixteenth century date is assigned.

Summarizing his survey of prehistoric Eskimo culture in Greenland, Dr. Mathiassen reconstructs their ethnic history by attributing to them an origin in arctic Canada, whence they came about a thousand years ago, with whale-bone houses and the Thule culture, to settle in the Cape York District. Thence they passed southward over Melville Bay to northern West Greenland, where they remained for several hundred years, encountering the Norsemen travelling northward, and changing the Thule culture into the Inugsuk culture. In the fourteenth century the growth of population forced them to seek new hunting fields. South Greenland was populated in the course of this century, the Norsemen being overrun. A group of Eskimo wandered around Cape Farewell to the east coast and far to the north along the coast. In the seventeenth century Polar Eskimo migrated north about Greenland and mixed with north-east Greenland's early population. Shortly afterwards, West Greenlanders reached Angmagssalik, while a small remnant of survivors from the first immigration to the east coast at Kangerdingssuaq died out, as also did the inhabitants of north-east Greenland. In West Greenland, however, the population grew rapidly, helped by Danish settlement; while at Cape York there was still a remnant of the old Thule Eskimo, helped by a new immigration from Baffinland.

On the general Eskimo problem, Dr. Mathiassen expresses the opinion that it cannot be solved in Greenland. $\mathrm{He}$ is, however, unable to accept $\mathrm{K}$. Birket-Smith's Caribou Eskimo theory, which makes Eskimo culture a link in a circumpolar inland culture, first created in the central parts of arctic Canada. The Thule culture points to Alaska and possibly Siberia.

\section{The Halle Academy, I652-I937}

$\mathrm{T}$ HE Kaiserlich Deutsche Akademie der Naturforscher at Halle has recently celebrated the two hundred and fiftieth anniversary of the granting of its charter. In 1652, soon after the end of the Thirty Years' War, there was founded by four physicians, in the Reichsstadt of Schweinfurth, a scientific society under the name of Academia Naturae Curiosorum. The principal founder and first president, Johann Lorenz Bausch, had studied in Italy and become acquainted with the local academies of that day, and especially with the Lyncæorum Academia, now Accademia Reale dei Lincei; he was also influenced by the writings of Bacon of Verulam. In 1677 the Emperor Leopold I recognized the society as the Academy of the Holy Roman Empire, and ten years later the same prince bestowed upon it considerable privileges and the title of Sacri Romani Imperii Academia Casareo-Leopoldina Natura Curiosorum. Arms were granted, with the motto: "Nunquam otiosus"; the president and the editor of the ephemerides received golden chains of office; they and their successors became counts palatine of the Holy Roman Empire ; as such they could legitimize bastards, confirm the liberation of slaves and perform other legal functions. They could, moreover, confer the titles of doctor, licentiate, master and bachelor, in the faculties of medicine, philosophy and laws; they could even appoint poets laureate. The doctorates so conferred were to secure the same privileges as those given by the universities. The publications of the Academy were exempted from censorship and protected as to copyright.

The Academy has survived the Empire from which its privileges were derived ; these privileges were never abolished, but their exercise fell into abeyance. So did the curious custom, recognized in the imperial charter of 1687 , of giving 'symbolic' names to its members; thus the first president was known as Jason I, his successor as Argonauta I. Meetings also fell into abeyance, and the activities of the Academy became restricted to the publication of a scientific periodical and to the administration of its library and museum. The location of the latter at first changed with that of the president, until the Academy became definitely established at Halle. Its natural history collections have been dispersed, but its library remains rich in valuable periodicals, of which a recently 